\title{
Liquidity volatility and spillover effects: evidence from the UK-USA and East Asian countries
}

\author{
SoM, Royal Holloway, \\ University of London, \\ Egham Hill, Egham, TW20 0EX, UK \\ Email: Sung.Lim.2009@live.rhul.ac.uk \\ Email: evangelos.giouvris@rhul.ac.uk \\ *Corresponding author
}

Sung Lim and Evangelos Giouvris*

\begin{abstract}
Most studies in the area of spillovers concentrate on return volatility and how this transmits between different markets. Liquidity volatility and potential spillovers on the other hand have attracted very little attention which is disproportional to the importance of liquidity. This empirical study makes an attempt to fill this gap in the literature and investigates liquidity volatility spillovers between the UK and East Asian stock markets (Japan, China, Hong Kong and Korea) and between the UK and the USA from 2006 to 2010. We use GARCH-M models and Granger causality tests. Liquidity is captured by absolute and proportional spread. Liquidity volatility for all countries in the sample is high and persistent. We also confirm the existence of significant liquidity volatility spillover effects using both methods mentioned above for UK-USA, UK-China, UK-Hong Kong and UK-Korea. Results for UK-Japan indicate that there is a weak spillover effect between the two countries if any at all.
\end{abstract}

Keywords: liquidity volatility; spillover effects; GARCH-M; Granger causality.

Reference to this paper should be made as follows: Lim, S. and Giouvris, E. (2015) 'Liquidity volatility and spillover effects: evidence from the UK-USA and East Asian countries', Int. J. Financial Engineering and Risk Management, Vol. 2, No. 1, pp.48-71.

Biographical notes: Sung Lim graduated from Royal Holloway, University of London with a $\mathrm{PhD}$ in Finance in 2014. This paper is part of his $\mathrm{PhD}$ thesis.

Evangelos Giouvris is currently working for Royal Holloway, University of London. He got his PhD from Durham Business School.

\section{Introduction}

As a branch of finance, market microstructure takes into account market frictions and trading costs to explore the link between market organisation and market quality such as efficiency, liquidity and volatility. This empirical study focuses on two dimensions of market quality, namely, liquidity and volatility in order to investigate liquidity spillover 
effects. According to the European Commission Report (Jeremie and Jean, 2008), the degree of international market integration has been increasing gradually. The report analyses market integration between three regions: North America, Europe and Asia. It shows that integration between Europe and Asia is lower than Europe and North America and Asia and North America. Since the spillover effect between markets is highly related to the degree of market integration, ${ }^{1}$ we would expect a significant spillover effect between North America and Europe and between North America and Asia. However the question that arises is what sort of effect to expect between Europe and Asia. Thus, it is necessary to investigate the existence of spillover effects between less researched markets, specifically, between the UK and Asia (Japan, Korea, China and Hong Kong). This study also includes the USA because it is the biggest and the most liquid stock market in the world.

Market microstructure literature, especially commonality in liquidity, has attracted a lot of attention (for the USA: Chordia et al., 2000; Huberman and Halka, 2001 and for the UK: Galariotis and Giouvris, 2007; Galariotis and Giouvris, 2009). Since the risk level of each market depends on liquidity, investors may use liquidity information as an important indicator to form their portfolios. Therefore, the degree of liquidity commonality could increase due to correlated trading which stems from various channels such as institutional investments, trade and financial linkages, inter-banking system, etc. Various researchers documented the relationship between individual liquidity and market wide liquidity and find common market-wide factors. ${ }^{2}$ While these studies focus on single markets, Chordia et al. (2005) examine the dependence of liquidity between different markets and show that shocks to liquidity in one market can have an impact on the liquidity in another market. ${ }^{3}$

Since the subprime crisis in 2007 , liquidity and in particular commonality in liquidity in international stock markets is becoming again a very hot topic. Several studies emphasise that increases in cross country correlation is consistent with capital market integration ${ }^{4}$ and commonality in liquidity is increasing during extreme market conditions and it spills over to other markets. ${ }^{5}$ Frank et al. (2008) point out the importance of interconnected financial markets and Nicolo and Ivaschenko (2008) emphasise various channels through which shocks can turn into serious market contagion. These various channels (asymmetric information, trade and financial linkages, inter-banking systems, institutional investors and indexation) might be the main vehicle which helps shocks spread worldwide and it causes co-movements in stock liquidity.

Other important dimensions are volatility and spillovers. Several authors emphasise that the stock price does not always reflect fundamentals but fluctuations due to incoming news which is often seen as price volatility. For instance, Eun and Shim (1989) examine volatility and show that it transmits across international stock markets. ${ }^{6}$ Jang and Sul (2002); Caporale et al. (2006) suggest that extreme price changes can transmit through volatility spillovers. Hamao et al. (1990) examined volatility spillover effects between New York, Tokyo and London stock markets using GARCH-M. They confirmed that there is a significant spillover effect from London and New York to Tokyo but not the other way around. Also Engle et al. (1990) investigate intraday volatility spillover between the USA and Japanese foreign exchange market using a multivariate GARCH model. ${ }^{7}$ They find that news which is revealed when one foreign exchange market is open contributes to the return volatility of the next market to open. 
While all of these papers analyse the spillover effect between stock returns and volatility, academic research on spillover effects associated with liquidity, however, is rather limited. The first attempt testing dependence of liquidity between the US equity and bond market have been made by Chordia et al. (2005). They use a vector autoregressive model and find that return volatility shocks predict an increase in bond liquidity. Also, Chordia et al. (2006), emphasise that shocks to liquidity in one market have a spillover effect across different sectors of stock markets. They show that liquidity innovations in either the large or small cap sector are informative in predicting liquidity. Chen and Poon (2007) report that stock market downturn Granger causes illiquidity while illiquidity does not Granger causes market downturn. Furthermore, Chan et al. (2005) investigate closed end country fund and show that illiquidity in one market can easily spillover to another and affect both the funds share price and its assets. Tang and Yan (2006) analyse liquidity spillovers to Credit Default Swap (CDS) markets. They find a significant liquidity spillover effect from bond, stock, option markets to the CDS market.

Unlike the study by Tang and Yan (2006) and other studies mentioned previously, this study concentrates on liquidity volatility spillovers in cross-country level. We adopt well established techniques to do that such as GARCH-M and Granger causality. The main purpose of this study is twofold. First, it investigates the aggregate stock market liquidity and level of volatility. Second, it examines the existence of spillover effect between international markets. This study focuses mainly on cross-country and time series properties of market-wide liquidity. Liquidity is measured as the aggregate of individual bid-ask spread. Although, Asian countries' economic relation and trading system with European countries have changed significantly since $1994,{ }^{8}$ a large body of literature is focused on the relationship between the USA and other countries, especially, when it looks at spillover effects associated with liquidity shocks. This study investigates if there are any liquidity volatility spillover effects between the UK and East Asian countries (Japan, Hong Kong, Korea and China) and it also includes the USA. It uses the following stock indexes: FTSE100, S\&P 100, NIKKEI 225, Hang Seng, KOSPI 100 and Shen Zhen 100. It presents a statistically significant liquidity volatility spillover effect between the UK and East Asian countries. Additionally, there are strong liquidity volatility spillover effects between the UK and the USA. This study confirms that changes in liquidity volatility in one market have a positive impact on the other market's liquidity volatility.

The rest of the paper is organised as follows. Section 2 discusses previous studies in the literature. Section 3 presents the data set and preliminary analysis of the two liquidity proxies for the six countries. The adopted methodology is presented in Section 4 and Section 5 discusses empirical results. Section 6 reports robustness tests. Finally, section 7 concludes.

\section{Literature review}

Rational expectations and the Efficient Market Hypothesis (EMH) often fail to explain the behaviour of extreme changes in stock prices because stock prices do not reflect fundamentals all the time. Stock price movements contain rational and irrational trading behaviour as a result of incoming news. Incoming news can be misinterpreted by 
ordinary investors. Also well informed investors may trade in ways that does not always make sense to ordinary investors. Trading based on different incentives moves the market but the direction of trade does not always make sense. This unexplained price movement is often expressed as stock price volatility and the degree of volatility is different between emerging stock markets and mature markets. De Santis and Imrohoroglu (1997) found evidence of time-varying volatility and show that the emerging stock markets are more volatile than developed stock markets.

\subsection{Volatility spillover effect on stock returns}

After the stock market crash (19 October 1987), interest in volatility spillover across international equity markets intensified and perpetuated a great effort to identify the relation between stock markets risk (conditional variance) and its expected return (conditional mean). Schwert (1990) analysed the market crash event in 1987 and remarked that this financial crisis was followed by a short period of extreme level of volatility. In the financial literature, the interdependence of volatility in international markets has been widely studied. Hamao et al. (1990) introduced the first paper examining volatility spillover effect between New York, Tokyo and London stock market using GARCH-M. They report that there is significant spillover effect from the US market and the UK market to the Japanese market while there is no significant spillover effect from Tokyo stock market to the London and the New York markets. However, it has been argued that the volatility spillover effect is due to the overlapping trading hours between the USA and the UK

Karolyi (1995) tests if there is transmission of stock returns and volatility between the USA and Canada and reports that stock returns' volatility in one market has an impact not only on conditional market returns but also on the conditional market volatility of the other market. Furthermore, Nelson (1991) develops the E-GARCH model in an attempt to capture the asymmetric impact of shocks on volatility and confirmed that an increase in volatility is caused by negative innovations rather than positive innovations. Koutmos and Booth (1995) support Nelson's findings by applying the model for New York, London and Tokyo. ${ }^{9}$

In Asian markets context, De Santis and Imrohoroglu (1997) analysed 15 emerging markets in terms of dynamics of expected stock returns and volatility and found that emerging markets are characterised by a higher and persistent volatility compared to the developed markets both at the conditional and unconditional level. After the Asian crisis in 1997, financial economists have been focusing on stock market interdependence within the Asian markets. Stock market interdependence and volatility in the Asian stock market during the Asian crisis is firstly investigated by In et al. (2001). They find that the Korean market plays a lesser role as an information producer and Hong Kong plays an important role in the transmission of volatility to other Asian markets. However, Chanchaoenchai and Dibooglu (2006) argue that the sudden fallout in Thailand seems to have played an important role. The crisis started in Thailand and then spread to other financial markets. Jang and Sul (2002) and Leong and Felmingham (2003) emphasise that the co-movement and causal relationship between Asian stock markets got stronger during the crisis. 


\subsection{Liquidity volatility and spillover effect}

Bernardo and Welch (2003) argue that the market making sector is risk averse and it cannot expand liquidity instantly. ${ }^{10}$ Thus, they emphasise investors' fear of future illiquidity as an important driving force of financial crisis. This study, however, could not explain how the market risk spreads across financial markets and institutions. Recently, market microstructure models find that the return volatility is a crucial factor in driving market illiquidity and identified the positive relationship between illiquidity and return volatility (Chordia et al., 2005; Deuskar, 2006; Chen and Poon, 2007). The first attempt to test if there is any dependence in liquidity between the US equity and bond market have been made by Chordia et al. (2005). They used a vector autoregressive model and found that shocks to liquidity in one market have an impact on the liquidity in the other market. More importantly, they find that liquidity and volatility shocks are positively correlated across stock and bond markets. Furthermore, Chordia et al. (2006) investigate persistent liquidity spillovers across different sectors of the stock market. They find that the liquidity innovations in either the large or small cap sector are informative in predicting liquidity and large cap stocks lead small cap in directional price moves, but small caps lead large caps in the discovery of volatility. Angelidis and Andrikopoulos (2010) investigate the London Stock Exchange and they show a significant returnvolatility spillover effect as well as liquidity spillover effect from large cap stocks to small cap stocks. Also they find that shocks in illiquidity can predict shocks in return volatility. Moreover, Tang and Yan (2006) show that illiquidity of other markets such as bond markets and stock markets spill over to the CDS market.

All previous studies discussed concentrated on stocks returns and volatility (A in Figure 1) liquidity and stock returns (B in Figure 1) and liquidity volatility and market returns ( $\mathrm{C}$ in Figure 1). This study however concentrates on (D in Figure 1) liquidity volatility and spillovers between the UK and selected Asian markets and draws elements from both bodies of literature: spillovers and liquidity.

Figure 1 Various dimensions of spillovers

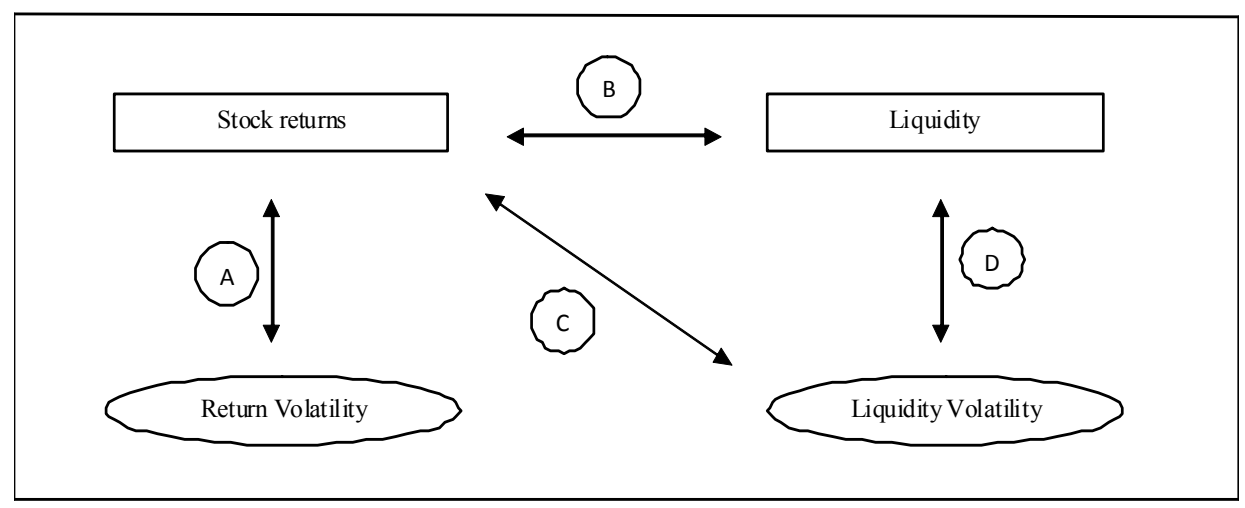




\section{Data and preliminary analysis}

\subsection{Data sampling}

We examine daily stock liquidity volatility and spillover effects across Asian markets and the UK. The US market is included as well. The sample period is from 10 April 2006 until 15 March 2010. ${ }^{11}$ This study uses Daily Average Absolute Bid-Ask Spread (ABS) and Daily Average Proportional Bid-Ask Spread (PRO) as a proxy of liquidity for six countries namely: the UK (FTSE100), the USA (S\&P100), Japan (NIKKEI225), Hong Kong (Hang Seng), China (Shen Zhen100) and Korea (KOSPI100). All data used in this paper is obtained from DATASTREAM. Daily Average ABS is constructed as follows: we take the difference between ask and bid price for each stock and then the spread is averaged over the day. Regarding the second liquidity variable, Daily Average PRO is estimated as follows: Absolute Spread/mid-quote where mid-quote is equal to (bid-price + ask-price)/2. All proxies are expressed in British pounds.

This empirical study uses a total of 1026 observations based on Monday-Friday trading but the actual number of observations has been reduced due to non-trading days. Although, NIKKEI is trading on Saturday, Saturday trading is excluded in order to synchronise trading days with FTSE100. Hence, the sample of FTSE100 is reduced to 992 daily observations, S\&P100 (989 observations), NIKKEI225 (964 observations), KOSPI100 (976 observations), Hang Seng (971 observations) and finally, China has the biggest reduction in total observations with 957 observations in total. The different changes in total observations for each market are due to the different holidays and no trading days for each country. For instance, countries in the sample have different nontrading days which are 34 days for the UK, 37days for the USA, 62 days for Japan, 55 days for Hong Kong, 69 days for China and 51 days for Korea. Since the main aim is to investigate the inter-relationship between the UK and East-Asian markets and of course the USA, we need to adjust the data set again which further reduces the number of total observations. For the UK and the USA, we obtain 971 trading days after synchronising the two markets' time series data set; for the UK and Japan 932 days, for the UK and Hong Kong 959 days, for the UK and China 924 days and for the UK and Korea 952 days.

Figure 2 presents various stock markets' opening hours. Opening hours in New York, represent late afternoon trading in London. East Asian markets open earlier than London and New York. The study investigates the relationship between the UK-USA and the UK-Asian markets. In order to examine the interactive spillover effect between the USA and Asian markets the data set requires further exclusion of non-trading days which causes non-stationarity. Estimating the regression model with non-stationary data could cause inconsistent results because standard errors and test statistics estimated with nonstationary data are invalid. ${ }^{12}$ Therefore, this study does not examine trading between the USA-East Asian Countries.

The study uses the close-to-close daily spread because the opening asks and bid price are not available. As this study uses the close-to-close price, changes in Asian markets could contain information from the USA. The information generated overnight is incorporated in the bid-ask price of Asian markets, thus it is possible to obtain strong liquidity spillover effects between the UK and Asian countries. 
Figure 2 Exchange trading hours

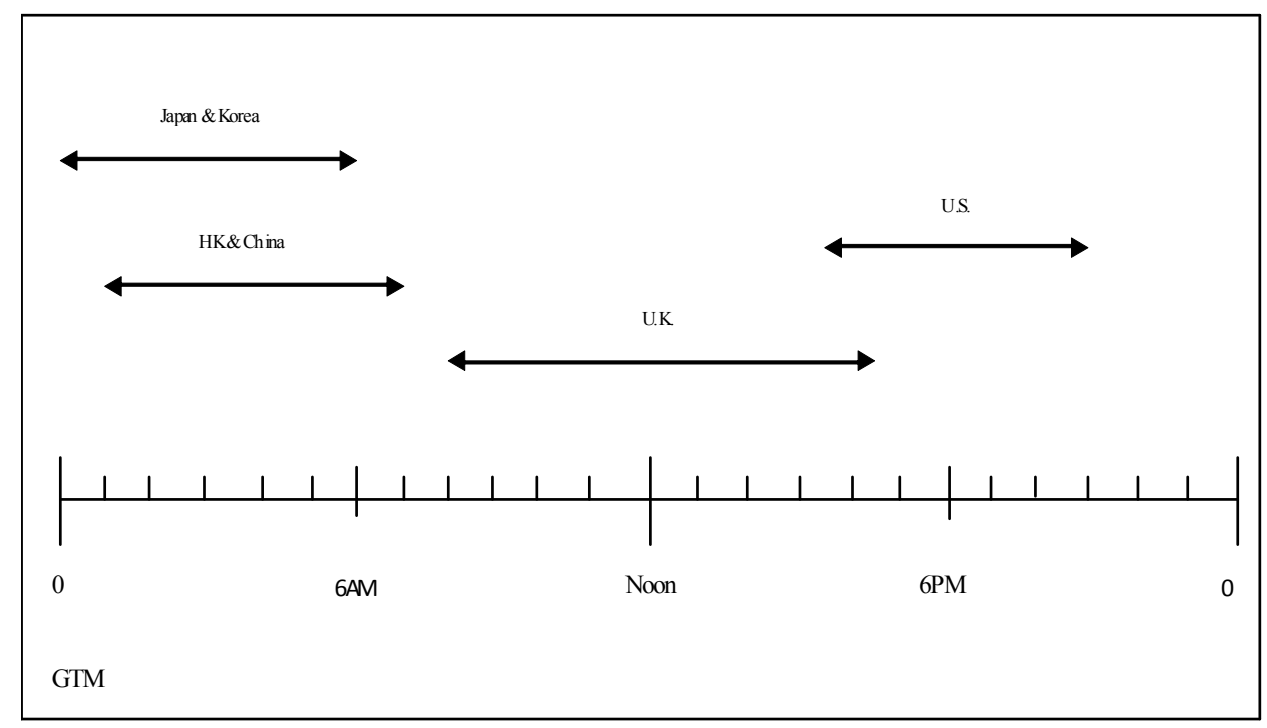

\subsection{Preliminary analysis}

This section presents some basic statistical tests such as stationarity tests, descriptive statistics and autocorrelation tests for the two spread proxies.

Stationarity is crucial for regression analysis. If non-stationarity is present, the series may increase or decrease over time which causes major problems with regression results such as biasness of the standard errors. In order to test for stationarity, we employ two unit root tests namely and Phillips-Perron (PP) test and Augmented Dickey-Fuller (ADF) test. For FTSE100, S\&P100, Hang Seng, Shen Zhen and KOSPI100, $\tau$-statistics are statistically significant at $1 \%$ and NIKKEI 225 is statistically significant at $5 \%$ level. ${ }^{13}$

Table 1 reports several descriptive statistics for the two spread proxies which are daily average ABS and daily average PRO. These include mean, standard deviation, skewness and kurtosis. Judging from the sample standard deviations for ABS, the UK is the most volatile market and the second most volatile market is Japan. Hong Kong shows the lowest level of liquidity volatility. When one looks at the preliminary statistics of PRO, the Chinese market is the most volatile and the second most volatile stock exchange is the Japanese market and for the rest of countries, the level of volatility is as follows (from highest to lowest): USA, Hong Kong, UK and Korea.

Clark (1973) and Blattberg and Gonedes (1974) documented that the unconditional distribution of financial returns exhibits fat tails and excess peakedness at the mean indicating that the returns series does not follow the normal distribution. Similarly, French and Roll (1986) and Bollerslev (1986) state that accumulation of information occurs during the market closing time which is reflected in prices when the markets reopen which creates daily seasonality. This phenomenon leads to a jump in stock prices and returns most of the time series that are not normally distributed. 
Table 1 Preliminary statistics on daily stock market liquidity

\begin{tabular}{|c|c|c|c|c|c|}
\hline \multicolumn{6}{|c|}{ Daily average absolute bid ask spread } \\
\hline Countries & Mean & $\begin{array}{l}\text { Standard } \\
\text { deviation }\end{array}$ & Skewness $\left(m_{2}\right)$ & Kurtosis $\left(m_{4}\right)$ & $J B$ \\
\hline UK & 1.267089 & 0.534272 & 2.018123 & 13.52011 & $\begin{array}{l}5131.440 \\
(0.0000)^{*}\end{array}$ \\
\hline USA & 0.025782 & 0.014042 & 2.578641 & 12.14988 & $\begin{array}{l}4458.681 \\
(0.0000)^{*}\end{array}$ \\
\hline Japan & 0.324934 & 0.117205 & 0.516946 & 2.735621 & $\begin{array}{l}44.22449 \\
(0.0000)^{*}\end{array}$ \\
\hline Hong Kong & 0.005883 & 0.001725 & 1.038931 & 4.951686 & $\begin{array}{l}321.6775 \\
(0.0000)^{*}\end{array}$ \\
\hline China & 0.001312 & 0.000652 & 5.824301 & 65.87869 & $\begin{array}{l}157442.7 \\
(0.0000)^{*}\end{array}$ \\
\hline Korea & 0.205541 & 0.065668 & 1.123616 & 4.483123 & $\begin{array}{l}36895.52 \\
(0.0000)^{*}\end{array}$ \\
\hline \multicolumn{6}{|c|}{ Daily average proportional bid ask spread } \\
\hline Countries & Mean & $\begin{array}{l}\text { Standard } \\
\text { deviation }\end{array}$ & Skewness $\left(m_{2}\right)$ & Kurtosis $\left(m_{4}\right)$ & $J B$ \\
\hline UK & 0.001740 & 0.000803 & 3.421345 & 33.06842 & $\begin{array}{l}38433.51 \\
(0.0000)^{*}\end{array}$ \\
\hline USA & 0.001194 & 0.000881 & 6.281518 & 63.06749 & $\begin{array}{l}151421.9 \\
(0.0000)^{*}\end{array}$ \\
\hline Japan & $2.02 \mathrm{e}-05$ & $9.32 \mathrm{e}-06$ & 1.625117 & 5.875316 & $\begin{array}{l}731.2884 \\
(0.0000)^{*}\end{array}$ \\
\hline Hong Kong & 0.000215 & $8.20 \mathrm{e}-05$ & 2.244138 & 10.84477 & $\begin{array}{l}3233.367 \\
(0.0000)^{*}\end{array}$ \\
\hline China & 0.001426 & 0.005230 & 5.922980 & 42.76489 & $\begin{array}{l}66495.75 \\
(0.0000)^{*}\end{array}$ \\
\hline Korea & 0.003089 & 0.000651 & 4.835318 & 50.78938 & $\begin{array}{l}93905.17 \\
(0.0000) *\end{array}$ \\
\hline
\end{tabular}

The statistics $m_{3}$ and $m_{4}$ are the standard measures of skewness and kurtosis, respectively. Under the null hypothesis of normality, $m_{3}$ and $m_{4}$ are asymptotically distributed as $m_{3} \sim N(0,6 / T)$ and $m_{4} \sim N(3,24 / T)$, where $T$ is the number of observations. In Table 1 , a skewness value of 2.018123 for the ABS in the UK shows that the distribution is positively skewed relative to the normal distribution ( 0 for the normal distribution). All countries (both ABS and PRO) have positively skewed distributions, which implies nonsymmetric series. Kurtosis is much larger than 3 (the kurtosis for a normal distribution) for all countries. Therefore, none of the time series data is normally distributed. This positively skewed distribution implies that all countries have some experiences of high illiquidity. 
Table 2 presents the autocorrelation coefficients of absolute and proportional spread. Under the null hypothesis of serial independence, $Q$ statistic follows the chi-squared distribution. The six countries' autocorrelation coefficients show persistence and are decaying very slowly. Also the coefficient and probability of the ACF test show a statistically significant result indicating the presence of serial correlation in the stock market liquidity series for both absolute and proportional spread. We perform ACF tests for the two daily liquidity proxies (ABS and PRO) by running the following regressions using a different number of lags each time.

$$
\begin{aligned}
& A B S_{t}=C+A B S_{t-1}+A B S_{t-2}+\ldots+A B S_{t-v}+e_{t} \\
& P R O_{t}=C+P R O_{t-1}+P R O_{t-2}+\ldots+P R O_{t-v}+e_{t}
\end{aligned}
$$

\subsection{Optimal lag structure}

In this part, the optimal lag-structure of $\operatorname{ARMA}(p, q)$ for each country is identified based on the Box-Jenkins methodology in order to filter out autoregressive and moving average effects from the sample before running the GARCH-M model. We detect the optimal lag of $\operatorname{ARMA}(p, q)$ for each country's two liquidity proxies by employing a number of different specifications namely autoregressive term only, moving average term only or a combination of the two. Due to the non-synchronous trading in each of the six countries, the optimal lag structure of ARMA is varying for each pair of countries. Table 3 summarises the order of ARMA. Panel A presents results for ABS and panel B present results for PRO.

Table 2 Autocorrelation coefficient for daily stock liquidity

\begin{tabular}{ccccccc}
\hline \multicolumn{7}{c}{ Panel A: (Daily average absolute bid ask spread) $^{a}$} \\
\hline \multirow{2}{*}{$A C F$} & UK & USA & Japan & Hong Kong & China & Korea \\
\hline \multirow{2}{*}{$\rho(1)$} & 0.698 & 0.584 & 0.797 & 0.476 & 0.582 & 0.290 \\
& $(0.000)$ & $(0.000)$ & $(0.000)$ & $(0.000)$ & $(0.000)$ & $(0.000)$ \\
\hline \multirow{2}{*}{$\rho(2)$} & 0.700 & 0.497 & 0.771 & 0.467 & 0.524 & 0.204 \\
& $(0.000)$ & $(0.000)$ & $(0.000)$ & $(0.000)$ & $(0.000)$ & $(0.000)$ \\
\hline \multirow{2}{*}{$\rho(3)$} & 0.750 & 0.512 & 0.759 & 0.485 & 0.524 & 0.219 \\
& $(0.000)$ & $(0.000)$ & $(0.000)$ & $(0.000)$ & $(0.000)$ & $(0.000)$ \\
\hline \multirow{2}{*}{$\rho(4)$} & 0.666 & 0.565 & 0.752 & 0.492 & 0.480 & 0.242 \\
& $(0.000)$ & $(0.000)$ & $(0.000)$ & $(0.000)$ & $(0.000)$ & $(0.000)$ \\
\hline \multirow{2}{*}{$\rho(5)$} & 0.664 & 0.450 & 0.726 & 0.484 & 0.471 & 0.230 \\
& $(0.000)$ & $(0.000)$ & $(0.000)$ & $(0.000)$ & $(0.000)$ & $(0.000)$ \\
\hline \multirow{2}{*}{$\rho(6)$} & 0.652 & 0.430 & 0.734 & 0.474 & 0.433 & 0.184 \\
& $(0.000)$ & $(0.000)$ & $(0.000)$ & $(0.000)$ & $(0.000)$ & $(0.000)$ \\
\hline \multirow{2}{*}{$\rho(7)$} & 0.647 & 0.540 & 0.719 & 0.419 & 0.483 & 0.275 \\
& $(0.000)$ & $(0.000)$ & $(0.000)$ & $(0.000)$ & $(0.000)$ & $(0.000)$ \\
\hline \multirow{2}{*}{$\rho(8)$} & 0.633 & 0.502 & 0.715 & 0.405 & 0.462 & 0.279 \\
& $(0.000)$ & $(0.000)$ & $(0.000)$ & $(0.000)$ & $(0.000)$ & $(0.000)$ \\
\hline \multirow{2}{*}{$\rho(9)$} & 0.634 & 0.433 & 0.711 & 0.462 & 0.461 & 0.215 \\
& $(0.000)$ & $(0.000)$ & $(0.000)$ & $(0.000)$ & $(0.000)$ & $(0.000)$ \\
\hline \multirow{2}{*}{$\rho(10)$} & 0.628 & 0.435 & 0.715 & 0.444 & 0.429 & 0.197 \\
& $(0.000)$ & $(0.000)$ & $(0.000)$ & $(0.000)$ & $(0.000)$ & $(0.000)$ \\
\hline
\end{tabular}


Liquidity volatility and spillover effects

Table 2 Autocorrelation coefficient for daily stock liquidity (continued)

\begin{tabular}{ccccccc}
\hline \multicolumn{7}{c}{ Panel B: (Daily average proportional bid ask spread) } \\
\hline \multirow{2}{*}{$A C F$} & $U K$ & USA & Japan & Hong Kong & China & Korea \\
\hline \multirow{2}{*}{$\rho(1)$} & 0.620 & 0.626 & 0.795 & 0.651 & 0.123 & 0.387 \\
& $(0.000)$ & $(0.000)$ & $(0.000)$ & $(0.000)$ & $(0.000)$ & $(0.000)$ \\
\hline \multirow{2}{*}{$\rho(2)$} & 0.631 & 0.529 & 0.759 & 0.623 & 0.079 & 0.331 \\
& $(0.000)$ & $(0.000)$ & $(0.000)$ & $(0.000)$ & $(0.000)$ & $(0.000)$ \\
\hline \multirow{2}{*}{$\rho(3)$} & 0.676 & 0.530 & 0.750 & 0.600 & 0.100 & 0.260 \\
& $(0.000)$ & $(0.000)$ & $(0.000)$ & $(0.000)$ & $(0.000)$ & $(0.000)$ \\
\hline \multirow{2}{*}{$\rho(4)$} & 0.587 & 0.568 & 0.739 & 0.576 & 0.049 & 0.309 \\
& $(0.000)$ & $(0.000)$ & $(0.000)$ & $(0.000)$ & $(0.000)$ & $(0.000)$ \\
\hline \multirow{2}{*}{$\rho(5)$} & 0.586 & 0.467 & 0.707 & 0.588 & 0.026 & 0.306 \\
& $(0.000)$ & $(0.000)$ & $(0.000)$ & $(0.000)$ & $(0.000)$ & $(0.000)$ \\
\hline \multirow{2}{*}{$\rho(6)$} & 0.574 & 0.439 & 0.718 & 0.582 & -0.005 & 0.256 \\
& $(0.000)$ & $(0.000)$ & $(0.000)$ & $(0.000)$ & $(0.000)$ & $(0.000)$ \\
\hline \multirow{2}{*}{$\rho(7)$} & 0.610 & 0.583 & 0.684 & 0.547 & 0.087 & 0.317 \\
& $(0.000)$ & $(0.000)$ & $(0.000)$ & $(0.000)$ & $(0.000)$ & $(0.000)$ \\
\hline \multirow{2}{*}{$\rho(8)$} & 0.560 & 0.536 & 0.665 & 0.536 & 0.043 & 0.257 \\
& $(0.000)$ & $(0.000)$ & $(0.000)$ & $(0.000)$ & $(0.000)$ & $(0.000)$ \\
\hline \multirow{2}{*}{$\rho(9)$} & 0.559 & 0.460 & 0.669 & 0.551 & 0.007 & 0.269 \\
& $(0.000)$ & $(0.000)$ & $(0.000)$ & $(0.000)$ & $(0.000)$ & $(0.000)$ \\
\hline \multirow{2}{*}{$\rho(10)$} & 0.555 & 0.443 & 0.672 & 0.548 & -0.022 & 0.231 \\
& $(0.000)$ & $(0.000)$ & $(0.000)$ & $(0.000)$ & $(0.000)$ & $(0.000)$ \\
\hline
\end{tabular}

Notes: Numbers in parentheses indicate probability.

${ }^{a}$ We run the following regression: $A B S_{t}=C+A B S_{t-1}+A B S_{t-2}+\ldots+$

$A B S_{t-v}+e_{t}$.

${ }^{\mathrm{b}}$ We run the following regression: $P R O_{t}=C+P R O_{t-1}+P R O_{t-2}+\ldots+$

$P R O_{t-v}+e_{t}$.

We estimate this regression with a different number of lags each time.

Table 3 Optimal lag structure of $\operatorname{ARMA}(p, q)$

\begin{tabular}{cccc}
\hline \multicolumn{4}{c}{ Panel A: Daily average absolute bid ask spread (ABS) } \\
\hline Group of country & Countries & $\operatorname{ARMA}(p, q)$ & LM test \\
\hline \multirow{2}{*}{ UK and USA } & UK & $\operatorname{ARMA}(3,6)$ & $0.084945(0.9584)$ \\
& USA & $\operatorname{ARMA}(5,6)$ & $0.597191(0.7419)$ \\
\hline \multirow{2}{*}{ UK and Japan } & UK & $\operatorname{ARMA}(5,3)$ & $3.694541(0.1577)$ \\
& Japan & $\operatorname{ARMA}(4,3)$ & $2.504358(0.2858)$ \\
\hline \multirow{2}{*}{ UK and Hong Kong } & UK & $\operatorname{ARMA}(6,3)$ & $0.043902(0.9783)$ \\
& Hong Kong & $\operatorname{ARMA}(7,7)$ & $0.086188(0.7691)$ \\
\hline \multirow{2}{*}{ UK and China } & UK & $\operatorname{ARMA}(3,4)$ & $0.892660(0.6400)$ \\
& China & $\operatorname{ARMA}(4,6)$ & $0.070238(0.9655)$ \\
\hline \multirow{2}{*}{ UK and Korea } & UK & $\operatorname{ARMA}(5,4)$ & $0.818323(0.6642)$ \\
& Korea & $\operatorname{ARMA}(6,5)$ & $1.336274(0.5127)$ \\
\hline
\end{tabular}


Table 3 Optimal lag structure of $\operatorname{ARMA}(p, q)$ (continued)

\begin{tabular}{cccc}
\hline \multicolumn{4}{c}{ Panel B: Daily average proportional bid ask spread (PRO) } \\
\hline Group of country & countries & ARMA $(p, q)$ & LM test \\
\hline \multirow{2}{*}{ UK and USA } & UK & $\operatorname{ARMA}(5,5)$ & $2.658961(0.2646)$ \\
& USA & $\operatorname{ARMA}(7,7)$ & $1.272822(0.5292)$ \\
\hline \multirow{2}{*}{ UK and Japan } & UK & Non-stationary & - \\
& Japan & Non-stationary & - \\
\hline \multirow{2}{*}{ UK and Hong Kong } & UK & $\operatorname{ARMA}(2,5)$ & $0.123777(0.9400)$ \\
& Hong Kong & $\operatorname{ARMA}(5,5)$ & $0.047876(0.8268)$ \\
\hline \multirow{2}{*}{ UK and China } & UK & $\operatorname{ARMA}(8,7)$ & $6.063863(0.0482)$ \\
& China & $\operatorname{ARMA}(6,5)$ & $2.026247(0.3631)$ \\
\hline \multirow{2}{*}{ UK and Korea } & UK & $\operatorname{ARMA}(6,6)$ & $1.562503(0.4578)$ \\
& Korea & $\operatorname{ARMA}(3,2)$ & $0.632652(0.7288)$ \\
\hline
\end{tabular}

Notes: The best fitting model of $\operatorname{ARMA}(p, q)$ is based on Akaike information Criterion. LM test: the LM test statistic is asymptotically distributed as $\chi^{2}(p)$. $H 0$ : No serial correlation up to lag order $p, H 1$ : Serial correlation up to lag order $p$. Probability-value in parentheses. UK (FTSE100), US (S\&P100), JAPAN (NIKKEI225), Hong Kong (HangSeng), China (ShenZhen100) and Korea (KOSPI100) is our sample.

In Panel A (ABS) LM-tests for all countries show that the: H0: No serial correlation is not rejected. In panel B (PRO) the majority of the countries' LM tests show that there is no serial correlation after fitting ARMA except the UK in the UK-China group in which the null hypothesis is rejected. This implies that the UK market has a long memory of liquidity and decays slowly to zero. However, when the GARCH-M model is estimated for this group, ARCH-LM test shows that there is no serial correlation remaining for the UK.

\section{Methodology}

Autoregressive Conditional Heteroskedasticity (ARCH) models are specifically designed to model and forecast conditional variances. The variance of the dependent variable is modelled as a function of past values of the dependent variable and independent or exogenous variables. The ARCH models were introduced by Engle (1982) and generalised as Generalised ARCH (GARCH) by Bollerslev (1986) and Taylor (1986). These models are widely used in various branches of econometrics, especially, in financial time series analysis.

\subsection{Adopted model}

In finance, the return of a security may depend on its volatility. To model such a phenomenon, one may consider introducing the conditional variance or standard deviation into the mean equation which is known as the GARCH-in-Mean (GARCH-M) model (Engle et al., 1990).

$$
\left.Y_{t}=c+\delta_{1} \sigma_{t}^{2}+\epsilon_{t} \text { (Mean equation }\right)
$$




$$
\begin{aligned}
& \epsilon_{t} \mid \Omega_{t-1} \sim N\left(0, \sigma_{t}^{2}\right) \\
& \sigma_{t}^{2}=\alpha_{0}+\alpha_{1} \in_{t-1}^{2}+\beta_{1} \sigma_{t-1}^{2} \quad \text { (Variance equation) }
\end{aligned}
$$

Where $c$ is a constant, the parameter $\delta_{1}$ is called the risk premium parameter. A positive $\delta_{1}$ indicates that the return is positively related to volatility because the expected return on an asset is related to the expected asset risk thus the estimated coefficient on the expected risk is a measure of the risk-return trade-off. This model is for relations between stock returns and its volatility. In order to investigate the effect of volatility on liquidity and the spillover effect, this study follows the method introduced by Hamao et al. (1990). They use GARCH-M model to estimate return volatility and spillover effect between New York, London and Tokyo stock exchange. In order to capture time varying volatility, they follow a MA(1)-GARCH(1, 1)-M model. Investigation of the spillover effect is fulfilled by placing recent return volatility shocks which occurred in the foreign market into the variance equation denoted by $X_{t-1}, X_{t-1}$ is obtained from the MA(1)$\operatorname{GARCH}(1,1)-\mathrm{M}$ model applied to the previous foreign market. Unlike the Hamao et al. study, this study uses $\operatorname{ARMA}(p, q)-\operatorname{GARCH}(1,1)-\mathrm{M}$ model employing two liquidity proxies (ABS and PRO). In order to build the model, we use Box-Jenkins methodology to remove serial correlation and moving average effects from the data set. The order of ARMA was based on the Akaike information criterion (1974).

In order to model liquidity volatility, the following model is adopted:

$$
\begin{aligned}
& L_{t}=c+\operatorname{ARMA}(p, q)+\delta_{1} \sigma_{t}^{2}+\delta_{2} D_{t}+\delta_{3} \in_{t-1}+\epsilon_{t}, \text { (Mean equation) } \\
& \sigma_{t}^{2}=c+\alpha_{1} \in_{t-1}^{2}+\beta_{1} \sigma_{t-1}^{2},(\text { Variance equation })
\end{aligned}
$$

where $L_{t}$ denotes liquidity (ABS and PRO) and $\sigma_{t}^{2}$ in the variance equation represents the conditional variance of the stock liquidity at time $t$ and $\sigma_{t}^{2}$ in the mean equation is the liquidity premium parameter. $D$ represents a dummy variable that takes a value of 1 on days following weekends and is 0 otherwise. In the variance equation, the volatility of liquidity in the market is obtained by the sum of $\alpha_{1}$ and $\beta_{1}$, which is expected to be less than 1 . So the model converges to long-term volatility.

At a later stage, we introduce an exogenous variable $X_{t-1}$ into the conditional variance equation that captures the potential liquidity volatility spillover effect of another market. The model is given in following equation (6).

$$
\begin{aligned}
& L_{t}=C+\operatorname{ARMA}(p, q)+\delta_{1} \sigma_{t}^{2}+\delta_{2} D_{t}+\delta_{3} \in_{t-1}+\epsilon_{t}, \text { (Mean equation) } \\
& \sigma_{t}^{2}=C+\alpha_{1} \in_{t-1}^{2}+\beta_{1} \sigma_{t-1}^{2}+\delta_{4} X_{t-1}+\delta_{5} D_{t}, \text { (Variance equation) }
\end{aligned}
$$

where the specifications of model (6) are the same as model (5) except $X_{t-1}$, which is the most recent liquidity volatility surprise observed in foreign markets (5). ${ }^{14}$

In order to estimate GARCH models, we use maximum likelihood to get the best fit of parameters. From preliminary analysis, in most cases, the conditional normality assumption does not hold. Under non-normality, the usual standard error estimates will be inappropriate; therefore, this study estimates the model with the Quasi-Maximum likelihood method. 


\section{Empirical results}

The main aims of the performed statistical analysis are: (a) to model liquidity volatility in the six countries in the sample; (b) to ascertain spillover effects of liquidity volatility between international stock markets. It examines how liquidity shocks generated in the UK stock market spill over East Asian countries' stock markets and the other way around. Additionally, this study investigates spillover effects between the UK and the USA. The following section presents the results for each of these objectives.

\subsection{Stock market liquidity volatility}

This study estimates time-varying volatility using the GARCH-M model between 10 April 2006 and 15 March 2010. The reason we choose this period of time is that ask price and bid price for the USA are not available before 10 April 2006 in our database. Table 4 presents the results of liquidity (absolute spread and proportional spread) volatility for all six stock exchanges. In the conditional variance equation, the sum of $\alpha_{1}$ and $\beta_{1}$ is expected to be less than but close to 1 indicating that the conditional volatility process is persistent and it is weakly stationary. We observe that liquidity volatility is persistent for all six countries. This initial estimation is for extracting volatility in order to investigate spillover effects.

For absolute spread (Table 4), the sum of $\alpha_{1}$ and $\beta_{1}$ for the UK is 0.9478 . The USA and Hong Kong market also present a persistent liquidity volatility level; the sum of the two parameters is 0.9929 and 0.9905 , respectively. The $\alpha_{1}+\beta_{1}$ for Japan is 0.9661 and 0.9480 for China. Korea's $\alpha_{1}+\beta_{1}$ is 0.9997 . Also, the coefficients of $\alpha_{1}$ and $\beta_{1}$ in all markets are statistically significant at the $1 \%$ level except $\alpha_{1}$ for Japan which is significant at $5 \%$ level. The general finding from these parameters is that $\beta_{1}$ in the conditional variance equation is considerably larger than $\alpha_{1}$, indicating that shocks to conditional variance takes a long time to die out so volatility is persistent. The low value of error coefficient $\alpha_{1}$ suggests that large market surprises induce relatively small revision in future volatility. The persistence of the conditional variance process, measured by $\alpha_{1}+$ $\beta_{1}$, is high and often close to 1 for all countries. This means that the current liquidity level is also relevant in predicting future liquidity volatility at a long horizon.

Table 4 Liquidity volatility

\begin{tabular}{|c|c|c|c|c|c|c|}
\hline \multicolumn{7}{|c|}{ Absolute bid-ask spread } \\
\hline & $U K$ & $U S A$ & $H K$ & $J A P$ & $\mathrm{CHI}$ & $K O R$ \\
\hline Dummy & $\begin{array}{l}-0.0071 \\
(0.4826)\end{array}$ & $\begin{array}{c}0.0010 \\
(0.0001)\end{array}$ & $\begin{array}{l}-0.0001 \\
(0.1767)\end{array}$ & $\begin{array}{l}-0.0102 \\
(0.0078)\end{array}$ & $\begin{array}{l}3.5 \mathrm{E}-05 \\
(0.0037)\end{array}$ & $\begin{array}{c}0.0010 \\
(0.7260)\end{array}$ \\
\hline$\alpha_{1}$ & $\begin{array}{c}0.1907 \\
(0.0002) \\
\end{array}$ & $\begin{array}{c}0.1485 \\
(0.0000) \\
\end{array}$ & $\begin{array}{c}0.0661 \\
(0.0000) \\
\end{array}$ & $\begin{array}{c}0.1403 \\
(0.0189) \\
\end{array}$ & $\begin{array}{c}0.2554 \\
(0.0037) \\
\end{array}$ & $\begin{array}{c}0.0515 \\
(0.0030) \\
\end{array}$ \\
\hline$\beta_{1}$ & $\begin{array}{c}0.7571 \\
(0.0000) \\
\end{array}$ & $\begin{array}{c}0.8434 \\
(0.0000) \\
\end{array}$ & $\begin{array}{c}0.9244 \\
(0.0000) \\
\end{array}$ & $\begin{array}{c}0.8258 \\
(0.0017) \\
\end{array}$ & $\begin{array}{c}0.6926 \\
(0.0000) \\
\end{array}$ & $\begin{array}{c}0.9482 \\
(0.0000) \\
\end{array}$ \\
\hline \multirow{3}{*}{$\begin{array}{l}\text { Ljung- } \\
\text { Box }\end{array}$} & $\begin{array}{c}\mathrm{Q}(12) 2.8698 \\
(0.412)\end{array}$ & $\begin{array}{c}Q(15) 10.339 \\
(0.016)\end{array}$ & $\begin{array}{c}\mathrm{Q}(15) 4.5569 \\
(0.033)\end{array}$ & $\begin{array}{c}\mathrm{Q}(08) 3.4179 \\
(0.064)\end{array}$ & $\begin{array}{c}Q(11) 8.6725 \\
(0.003)\end{array}$ & $\begin{array}{c}\mathrm{Q}(12) 6.3787 \\
(0.012)\end{array}$ \\
\hline & $\begin{array}{c}\mathrm{Q}(22) 9.1415 \\
(0.762)\end{array}$ & $\begin{array}{c}\mathrm{Q}(25) 18.595 \\
(0.136)\end{array}$ & $\begin{array}{c}\mathrm{Q}(25) 7.9074 \\
(0.722)\end{array}$ & $\begin{array}{c}\mathrm{Q}(22) 15.615 \\
(0.408)\end{array}$ & $\begin{array}{c}\mathrm{Q}(20) 13.925 \\
(0.176)\end{array}$ & $\begin{array}{l}\mathrm{Q}(20) 11.751 \\
\quad(0.228)\end{array}$ \\
\hline & $\begin{array}{c}\mathrm{Q}(32) 16.041 \\
(0.854)\end{array}$ & $\begin{array}{c}\mathrm{Q}(36) 35.512 \\
(0.061)\end{array}$ & $\begin{array}{c}\mathrm{Q}(35) 16.291 \\
(0.753)\end{array}$ & $\begin{array}{c}\mathrm{Q}(32) 25.118 \\
(0.512)\end{array}$ & $\begin{array}{c}\mathrm{Q}(30) 23.624 \\
(0.259)\end{array}$ & $\begin{array}{c}\mathrm{Q}(30) 23.472 \\
(0.217)\end{array}$ \\
\hline $\begin{array}{l}\text { ARCH- } \\
\text { LM } \\
\end{array}$ & $\begin{array}{r}0.0172 \\
(0.8959) \\
\end{array}$ & $\begin{array}{c}0.8613 \\
(0.3534) \\
\end{array}$ & $\begin{array}{r}0.3354 \\
(0.5625) \\
\end{array}$ & $\begin{array}{c}0.0801 \\
(0.7772) \\
\end{array}$ & $\begin{array}{c}0.0051 \\
(0.9433)\end{array}$ & $\begin{array}{c}0.7470 \\
(0.3874)\end{array}$ \\
\hline
\end{tabular}


Table 4 Liquidity volatility (continued)

\begin{tabular}{|c|c|c|c|c|c|c|}
\hline \multicolumn{7}{|c|}{ Proportional bid-ask spread } \\
\hline & $U K$ & $U S A$ & $H K$ & $J A P$ & $\mathrm{CHI}$ & $K O R$ \\
\hline Dummy & $\begin{array}{c}-2.0 \mathrm{E}-05 \\
(0.1255)\end{array}$ & $\begin{array}{c}-1.57 \mathrm{E} 05 \\
(0.0052)\end{array}$ & $\begin{array}{c}-6.0 \mathrm{E}-06 \\
(0.0197)\end{array}$ & - & $\begin{array}{l}2.3 \mathrm{E}-05 \\
(0.7238)\end{array}$ & $\begin{array}{c}-9.7 \mathrm{E}-09 \\
(0.4361)\end{array}$ \\
\hline$\alpha_{1}$ & $\begin{array}{c}0.2327 \\
(0.0000)\end{array}$ & $\begin{array}{c}0.0807 \\
(0.0000)\end{array}$ & $\begin{array}{c}0.1043 \\
(0.0000)\end{array}$ & - & $\begin{array}{c}0.1297 \\
(0.0000)\end{array}$ & $\begin{array}{c}0.0406 \\
(0.0184)\end{array}$ \\
\hline$\beta_{1}$ & $\begin{array}{c}0.6945 \\
(0.0000)\end{array}$ & $\begin{array}{c}0.8701 \\
(0.0000)\end{array}$ & $\begin{array}{c}0.8555 \\
(0.0000)\end{array}$ & - & $\begin{array}{c}0.6929 \\
(0.0000)\end{array}$ & $\begin{array}{c}0.9052 \\
(0.0000)\end{array}$ \\
\hline \multirow{3}{*}{ Ljung-Box } & $\begin{array}{c}\mathrm{Q}(16) 15.322 \\
(0.004)\end{array}$ & $\begin{array}{c}Q(12) 16.551 \\
(0.000)\end{array}$ & $\begin{array}{l}\mathrm{Q}(11) 6.316 \\
\quad(0.012)\end{array}$ & - & $\begin{array}{c}\mathrm{Q}(12) 1.7620 \\
(0.184)\end{array}$ & $\begin{array}{c}Q(12) 12.167 \\
(0.095)\end{array}$ \\
\hline & $\begin{array}{c}\mathrm{Q}(26) 28.727 \\
(0.011)\end{array}$ & $\begin{array}{l}\mathrm{Q}(22) 24.201 \\
(0.012)\end{array}$ & $\begin{array}{l}\mathrm{Q}(20) 9.904 \\
(0.449)\end{array}$ & - & $\begin{array}{c}\mathrm{Q}(20) 2.1879 \\
(0.988)\end{array}$ & $\begin{array}{c}\mathrm{Q}(20) 20.011 \\
(0.172)\end{array}$ \\
\hline & $\begin{array}{c}\mathrm{Q}(36) 40.380 \\
(0.019)\end{array}$ & $\begin{array}{c}\mathrm{Q}(32) 30.030 \\
(0.091)\end{array}$ & - & - & $\begin{array}{c}\mathrm{Q}(30) 6.3951 \\
(0.996)\end{array}$ & $\begin{array}{c}\mathrm{Q}(36) 48.198 \\
(0.025)\end{array}$ \\
\hline ARCH-LM & $\begin{array}{c}0.0002 \\
(0.9903)\end{array}$ & $\begin{array}{c}0.0149 \\
(0.9027)\end{array}$ & $\begin{array}{c}0.4241 \\
(0.5149)\end{array}$ & - & $\begin{array}{c}0.0185 \\
(0.8917)\end{array}$ & $\begin{array}{c}0.0549 \\
(0.8146)\end{array}$ \\
\hline
\end{tabular}

Notes: $\quad \operatorname{Liq}_{i, t}=C+\operatorname{ARMA}(p, q)+\delta_{1} \sigma_{t}^{2}+\delta_{2} D_{i, t}+\epsilon_{i, t}$

$$
\sigma_{t}^{2}=c+\alpha_{1} \epsilon_{t-1}^{2}+\beta_{1} \sigma_{t-1}^{2}
$$

Where $L i q_{i, t}$ stands for liquidity measure such as absolute bid-ask spread and proportional bid-ask spread for each country. The order of $\operatorname{ARMA}(p, q)$ is based on Table 3 for each country. $\sigma_{t}^{2}$ is conditional variance of liquidity and the $D$ is the weekend dummy variable that equals 1 on a day following a weekend or holiday or 0 otherwise. Countries are the UK (FTSE100), the US (S\&P100), Hong Kong (Hang Seng), Japan (NIKKEI 225), China (Shen Zhen $100)$ and Korea (KOSPI 100). The ARCH-LM test decision rule: HO: there is no ARCH up to order $q$ in the residual $\rightarrow$ Do not reject when $p$-value is high $\left(Q<\chi^{2}(\mathrm{lag})\right), p$-value in parentheses.

The USA, Japan and China present a significant dummy variable, which means that there is weekend effect for these markets. This implies that the bid-ask spread increases on Monday or the day after a holiday for these three markets. Finally, ARCH-LM tests show that the model for the six markets above have no further $\mathrm{ARCH}$ effects remaining in the model.

With respect to proportional spread (see Table 4), NIKKEI 225 is non-stationary. The sum of $\alpha_{1}$ and $\beta_{1}$ is 0.9272 for the UK, 0.9501 for the USA, 0.9598 for Hong Kong, 0.9458 for Korea and 0.8226 for China. Also these parameters are statistically significant at conventional levels. In terms of dummy variable, the USA and Hong Kong markets present a significant dummy variable indicating a weekend effect for these markets. ARCH-LM tests show that the model for the five markets above have no further ARCH effects remaining in the model.

Overall, this study finds a persistent liquidity volatility level in both absolute and proportional spread for all countries. Also, we obtain a persistent weekend effect for the USA, as the coefficient of dummy variables in both absolute and proportional spread is significant. Finally, ARCH-LM tests show that the model for the six markets above have no further ARCH effect remaining in the model. 


\subsection{Spillover effect of stock market liquidity}

To capture the volatility spillover effect, the study employs $\operatorname{ARMA}(p, q)-\operatorname{GARCH}(1,1)-$ $\mathrm{M}$ model as it was discussed in section 4. Results of the spillover effect are presented in Table 5. The parameter $X_{t-1}$ in equation (6) can be interpreted as the most recent volatility surprise observed in the foreign market. Even though the finance literature provides ambiguous empirical findings in international stock markets' spillover effects, this study expects $X_{t-1}$ to be statistically significant between the UK and other countries due to enhanced market integration. The primary purpose is to detect spillover effects between international stock markets. More precisely, this study is interested in investigating whether liquidity shocks which occurred in the UK stock market (East Asian markets) spill over to major East Asian stock markets (the UK stock market). We also add the USA market in order to investigate potential spillover effects among the biggest two markets (the UK and the USA). However, this study does not examine if there are any effects between the USA and the East Asian stock markets because this requires a further reduction of the sample size due to non-synchronous trading. Even though we tried to investigate liquidity spillover effects before and after the crisis, liquidity variables became non-stationary. ${ }^{15}$

Table 5 Spillover effect estimation

\begin{tabular}{cccccccc}
\hline & \multicolumn{7}{c}{ Absolute bid-ask spread } \\
\hline \multirow{2}{*}{$\mathrm{UK} \rightarrow \mathrm{US}$} & -0.0005 & 0.2697 & 0.6408 & $-2 \mathrm{E}-07$ & $-1.1 \mathrm{E}-05$ & $\mathrm{Q}(36) 32.683$ & 0.0039 \\
& $(0.0882)$ & $(0.0000)$ & $(0.0000)$ & $0.8959)$ & $(0.0000)$ & $(0.110)$ & $(0.9498)$ \\
\hline \multirow{2}{*}{$\mathrm{US} \rightarrow \mathrm{UK}$} & -0.0094 & 0.2153 & 0.7365 & 0.0020 & 0.1949 & $\mathrm{Q}(36) 16.862$ & 0.0170 \\
& $(0.3399)$ & $(0.0003)$ & $(0.0000)$ & $(0.7957)$ & $(0.4838)$ & $(0.934)$ & $(0.8961)$ \\
\hline \multirow{2}{*}{$\mathrm{UK} \rightarrow \mathrm{HK}$} & 0.0001 & 0.0544 & 0.9365 & $-1.2 \mathrm{E}-07$ & 0.0001 & $\mathrm{Q}(35) 26.893$ & 0.7705 \\
& $(0.0222)$ & $(0.0001)$ & $(0.0000)$ & $(0.3090)$ & $(0.0612)$ & $(0.138)$ & $(0.3800)$ \\
\hline \multirow{2}{*}{$\mathrm{HK} \rightarrow \mathrm{US}$} & -0.0069 & 0.2094 & 0.7316 & -0.0021 & 13.6107 & $\mathrm{Q}(35) 18.836$ & 0.0163 \\
& $(0.4630)$ & $(0.0002)$ & $(0.0000)$ & $(0.7907)$ & $(0.7261)$ & $(0.875)$ & $(0.8984)$ \\
\hline \multirow{2}{*}{$\mathrm{UK} \rightarrow \mathrm{JAP}$} & -0.0102 & 0.1403 & 0.8105 & 0.0008 & -0.00004 & $\mathrm{Q}(35) 30.187$ & 1.3223 \\
& $(0.0078)$ & $(0.0021)$ & $(0.0000)$ & $(0.2336)$ & $(0.9487)$ & $(0.354)$ & $(0.2501)$ \\
\hline \multirow{2}{*}{$\mathrm{JAP} \rightarrow \mathrm{UK}$} & -0.0103 & 0.1819 & 0.7718 & 0.0046 & 0.0430 & $\mathrm{Q}(35) 20.893$ & 0.0267 \\
& $(0.2619)$ & $(0.0008)$ & $(0.0000)$ & $(0.5298)$ & $(0.0932)$ & $(0.747)$ & $(0.8699)$ \\
\hline \multirow{2}{*}{$\mathrm{UK} \rightarrow \mathrm{CHI}$} & -0.0004 & 0.1572 & 0.6099 & $7.04 \mathrm{E}-08$ & $2.3 \mathrm{E}-07$ & $\mathrm{Q}(35) 37.492$ & 0.6745 \\
& $(0.0000)$ & $(0.0000)$ & $(0.0000)$ & $(0.0000)$ & $(0.0000)$ & $(0.051)$ & $(0.4115)$ \\
\hline \multirow{2}{*}{$\mathrm{CHI} \rightarrow \mathrm{UK}$} & 0.0041 & 0.2380 & 0.7161 & 0.0014 & 2.5249 & $\mathrm{Q}(35) 19.927$ & 0.0186 \\
& $(0.6982)$ & $(0.0000)$ & $(0.0000)$ & $(0.8668)$ & $(0.6509)$ & $(0.887)$ & $(0.8914)$ \\
\hline \multirow{2}{*}{$\mathrm{UK} \rightarrow \mathrm{KOR}$} & -0.0061 & 0.0534 & 0.9462 & -0.00003 & 0.0001 & $\mathrm{Q}(35) 25.441$ & 1.3588 \\
& $(0.0459)$ & $(0.0094)$ & $(0.0000)$ & $(0.9329)$ & $(0.7406)$ & $(0.415)$ & $(0.2437)$ \\
\hline \multirow{2}{*}{$\mathrm{KOR} \rightarrow \mathrm{UK}$} & -0.0333 & 0.1370 & 0.5112 & -0.2028 & -0.5954 & $\mathrm{Q}(35) 33.661$ & 0.2306 \\
& $(0.0048)$ & $(0.0172)$ & $(0.0000)$ & $(0.0109)$ & $(0.0183)$ & $(0.143)$ & $(0.6311)$ \\
\hline
\end{tabular}


Table 5 Spillover effect estimation (continued)

\begin{tabular}{cccccccc}
\hline \multicolumn{7}{c}{ Proportional bid-ask spread } \\
\hline \multirow{2}{*}{$\mathrm{UK} \rightarrow \mathrm{US}$} & 0.00002 & 0.1823 & 0.6165 & $-5.6 \mathrm{E}-09$ & $-2.3 \mathrm{E}-06$ & $\mathrm{Q}(35) 0.0022$ & 0.0729 \\
& $(0.0181)$ & $(0.0000)$ & $(0.0000)$ & $(0.0000)$ & $(0.0677)$ & $(0.000)$ & $(0.7871)$ \\
\hline \multirow{2}{*}{$\mathrm{US} \rightarrow \mathrm{UK}$} & $8.3 \mathrm{E}-08$ & 0.1863 & 0.7081 & $-1.5 \mathrm{E}-09$ & $9.67 \mathrm{E}-06$ & $\mathrm{Q}(35) 42.643$ & 0.00001 \\
& $(0.9952)$ & $(0.0000)$ & $(0.0000)$ & $(0.8244)$ & $(0.0867)$ & $(0.007)$ & $(0.9969)$ \\
\hline \multirow{2}{*}{$\mathrm{UK} \rightarrow \mathrm{HK}$} & $-6.6 \mathrm{E}-06$ & 0.0828 & 0.8895 & $-1.1 \mathrm{E}-10$ & $1.2 \mathrm{E}-07$ & $\mathrm{Q}(35) 11.439$ & 0.5846 \\
& $(0.0066)$ & $(0.0001)$ & $(0.0000)$ & $(0.4958)$ & $(0.2511)$ & $(0.990)$ & $(0.4445)$ \\
\hline \multirow{2}{*}{$\mathrm{HK} \rightarrow \mathrm{US}$} & 0.00007 & 0.00003 & 0.2451 & $-3.23 \mathrm{E}-09$ & $1.7 \mathrm{E}-05$ & $\mathrm{Q}(35) 119.51$ & 1.1739 \\
& $(0.5858)$ & $(0.5361)$ & $(0.0000)$ & $(0.4304)$ & $(0.0783)$ & $(0.000)$ & $(0.2785)$ \\
\hline \multirow{2}{*}{$\mathrm{UK} \rightarrow \mathrm{JAP}$} & - & - & - & - & - & - & - \\
\hline \multirow{2}{*}{$\mathrm{JAP} \rightarrow \mathrm{UK}$} & - & - & - & - & - & - & - \\
\hline \multirow{2}{*}{$\mathrm{UK} \rightarrow \mathrm{CHI}$} & $-4.5 \mathrm{E}-05$ & 0.1556 & 0.5499 & $-2.5 \mathrm{E}-07$ & 0.0201 & $\mathrm{Q}(35) 21.174$ & 0.0399 \\
& $(0.8277)$ & $(0.0000)$ & $(0.0000)$ & $(0.1465)$ & $(0.0000)$ & $(0.628)$ & $(0.8416)$ \\
\hline \multirow{2}{*}{$\mathrm{CHI} \rightarrow \mathrm{UK}$} & $-6.8 \mathrm{E}-07$ & 0.1521 & 0.7403 & $-5.8 \mathrm{E}-11$ & $6.4 \mathrm{E}-09$ & $\mathrm{Q}(35) 31.073$ & 0.0021 \\
& $(0.5211)$ & $(0.0000)$ & $(0.0000)$ & $(0.0062)$ & $(0.0005)$ & $(0.072)$ & $(0.9634)$ \\
\hline \multirow{2}{*}{$\mathrm{UK} \rightarrow \mathrm{KOR}$} & $-7.7 \mathrm{E}-09$ & 0.0525 & 0.8848 & $-2.1 \mathrm{E}-14$ & $1.7 \mathrm{E}-11$ & $\mathrm{Q}(35) 47.776$ & 0.2726 \\
& $(0.4994)$ & $(0.0269)$ & $(0.0000)$ & $(0.0019)$ & $(0.0242)$ & $(0.028)$ & $(0.6015)$ \\
\hline \multirow{2}{*}{$\mathrm{KOR} \rightarrow \mathrm{UK}$} & $-1.9 \mathrm{E}-05$ & 0.1151 & 0.6819 & $3.3 \mathrm{E}-09$ & 0.0233 & $\mathrm{Q}(35) 30.804$ & 0.0070 \\
& $(0.1391)$ & $(0.0000)$ & $(0.0000)$ & $(0.6704)$ & $(0.0009)$ & $(0.127)$ & $(0.9329)$ \\
\hline
\end{tabular}

Notes: $\quad \operatorname{Liq}_{i, t}=C+\operatorname{ARMA}(p, q)+\delta_{1} \sigma_{t}^{2}+\delta_{2} D_{i, t}+\epsilon_{i, t}$

$\sigma_{t}^{2}=c+\alpha_{1} \epsilon_{t-1}^{2}+\beta_{1} \sigma_{t-1}^{2}+\gamma_{1} D_{j, t}+\gamma_{2} X_{j, t-1}$

Where $L i q_{i, t}$ stands for liquidity measure for each country. We use two liquidity measures such as absolute bid-ask spread and proportional bid-ask spread. The order of $\operatorname{ARMA}(p, q)$ is based on Table 4 for each country. $\sigma_{t}^{2}$ is conditional variance of liquidity and the $D$ is the weekend dummy variable that equals 1 on a day following a weekend or holiday or 0 otherwise. $X_{j, t-1}$ is the residual derived from the liquidity volatility of foreign market at time $t-1 . D_{j, t}$ is the weekend dummy variable of foreign market. Countries are the UK (FTSE100), the US (S\&P100), Hong Kong (Hang Seng), Japan (NIKKEI 225), China (Shen Zhen 100) and Korea (KOSPI 100). The ARCH-LM test decision rule: HO: there is no ARCH up to order $q$ in the residual $\rightarrow$ Do not reject when $p$ value is high $\left(Q<\chi^{2}(\mathrm{lag})\right), p$-value in parentheses.

\subsubsection{UK and USA}

First, we interpret absolute spread results. Results show a statistically significant spillover effect from the UK to the USA. The coefficient estimated on the volatility surprise from the UK to the USA, $\gamma_{2}$ is statistically significant at the $1 \%$ level. There is no significant spillover effect from the USA to the UK when ABS is used. When proportional spread is used, there is a two way relationship between the UK and the USA. The coefficients of spillover effects $\left(\gamma_{2}\right)$ from the USA to the UK and from the UK to the USA are 9.67E-06 and -2.3E-06, respectively, and both of them are statistically significant at $10 \%$ level. The model has been tested for misspecification using ARCH LM test and we find no further ARCH effects in the models. As it was expected, there are 
significant spillover effects between the USA and the UK. The coefficient of $\alpha_{1}$ and $\beta_{1}$ shows strong persistent liquidity volatility in the both markets. Interestingly, the USA market seems to have a significant weekend effect $\left(\delta_{2}\right.$ and $\left.\gamma_{1}\right)$ while the UK market does not have a significant weekend effect.

A strong volatility spillover from the USA to the UK has been reported in the literature (Theodossiou and Lee 1993; Theodossiou et al., 1997). Our study shows that there is a bi-directional spillover effect between the UK and the USA which is consistent with Martens and Poon (2001). Actually Martens and Poon (2001) report that this is the first time that a spillover effect has been reported from the UK to the USA. In the words of Martens and Poon: 'Previous studies have reported finding a volatility spillover effect from the USA to the other countries. Here, we find also a reverse volatility spillover from Europe to the USA'. Their sample ranges from August 1990 to November 1998. Our sample ranges from 2006 to 2010 indicating that the spillover effect from the UK to the USA discovered for the first time in their paper continues to exist. In addition Martens and Poon (2001) find that there is a spillover from France to the USA. Another paper that provides further support to our finding is that by Meric et al. (2008). They examine the long-term co-movement of the USA, UK and six major Asian stock markets (Australia, China, India, Japan, Korea and Russia) during a five year period before and after 11 September 2001. They used correlation analysis, Principal Components Analysis (PCA) and Granger causality tests. They find that the past returns of the UK stock market could predict the US stock market returns in both periods before and after 11 September 2011. If past UK returns predict US returns then it is very likely that there is a liquidity volatility spillover. The spillover effect from the UK to the USA could be explained by two channels such as trading and financial linkages. According to the CIA world factbook, the USA is the second biggest export partner and third biggest import partner for the UK. ${ }^{16}$ Thus, the significant spillover effect between the two markets is possibly due to their trading partnership. Secondly, Bayoumi and Swiston (2009) find that financial linkages are the most important channel that transmits shocks between countries (the USA, Euro area and Japan) especially during the recent financial crisis. Now as far as policy implications are concerned, this finding may have an effect on forming suitable hedging strategies, forecasting and obtaining VaR estimates. The effect of spillovers should be considered in the design of VaR models otherwise there is a danger of obtaining volatile hedge ratios. Failure to provide accurate VaR estimates as a result of leaving out the effect of the UK to the USA could lead to non-conformance to Bank of International Settlements regulations.

\subsubsection{UK and Hong Kong}

A spillover effect is detected from the UK to Hong Kong. The coefficient $\gamma_{2}$ for ABS is 0.00013 ( $p$-value of 0.0612). There is no spillover effect from Hong Kong to the UK when using absolute spread. When we test for a spillover effect with proportional spread, we obtain a statistically significant (at 10\%) spillover effect from Hong Kong to the UK. The coefficient $v_{2}$ is 0.000017 ( $p$-value of 0.0783 ). There is no spillover effect from the UK to Hong Kong. The ARCH-LM tests show that there is no ARCH effect remaining. Generally speaking the results obtained do not help establish a clear relation between Hong Kong and the UK. 


\subsubsection{UK and Japan}

In this empirical test, only absolute spread is examined since proportional spread for NIKKEI 225 is non-stationary. The coefficient of spillover effect generated from the UK to Japan is statistically insignificant indicating that liquidity shocks in the UK do not spill over to the Japanese stock market. However, we find evidence of spillover effects from Japan to the UK. The coefficient of spillover is 0.043 ( $p$-value: 0.0932). The ARCH-LM test shows that there is no further ARCH effect in the model.

\subsubsection{UK and China}

When we use daily absolute spread, we confirm a spillover effect from the UK to China. The coefficient of spillover effect $\left(\gamma_{2}\right)$ for the Chinese market is $2.3 \mathrm{E}-07$ and it is statistically significant at $1 \%$ while there is no spillover effect from China to the UK. The coefficient is insignificant (2.5249 and $p$-value of 0.6509). However, based on proportional spread, we find a strong spillover effect between the UK and China. $X_{t-1}$ in the conditional variance equation is statistically significant at the $1 \%$ level in both directions. Thus, liquidity shocks from these two markets are transmitting to each other. $\mathrm{ARCH}$ LM test does not reject the null hypothesis of no further $\mathrm{ARCH}$ effect in the model for all tests.

\subsubsection{UK and Korea}

Table 5 shows no spillover effect from Korea to the UK for absolute spread. The coefficient of spillover effect is -0.0001 ( $p$-value of 0.7406 ). From the UK to Korea, the coefficient of $X_{t-1}$ for absolute spread is -0.5954 and the $p$-value is 0.0183 indicating a statistically significant spillover effect. Proportional spread shows a significant spillover between the UK and Korea. The coefficient of spillover parameter $\left(\gamma_{2}\right)$ on the UK market is 0.0233 and its $p$-value is 0.0009 . The coefficient of $X_{t-1}$ for Korea is $1.72 \mathrm{E}-11$ and $p$ value is 0.0242 . Thus, liquidity shocks from these two markets are transmitting to each other. ARCH-LM tests show that there is no ARCH effect in the model.

From the summary table of spillover effects (Table 6), one can say that shocks of liquidity volatility in the UK are transmitted (either through ABS or PRO) to all countries except Japan. The Japanese stock market appears to be more robust to exogenous risks compared to other Asian markets and in particular to the UK liquidity spillovers. The existence of a spillover effect from Japan to the UK could be the overnight effect that contains early information generated by the US market.

Table 6 Summary of spillover effect

\begin{tabular}{c|c|c|c|c}
\hline \multirow{2}{*}{ UK and USA } & \multicolumn{2}{|c|}{ ABS } & \multicolumn{2}{c}{ PRO } \\
\cline { 2 - 5 } & To UK & To USA & To UK & To USA \\
\hline \multirow{2}{*}{ From UK } & & $\rightarrow$ & $\times$ & \\
\hline From USA & \multicolumn{2}{|c|}{ ABS } & To UK & To Hong Kong \\
\hline \multirow{2}{*}{ UK and HK } & \multicolumn{2}{|c|}{ To UK } & To Hong Kong & PRO \\
\cline { 2 - 5 } & \multicolumn{2}{|c|}{$\rightarrow$} & $\rightarrow$ & \\
\hline From UK & $\times$ & & \\
\hline
\end{tabular}


Table 6 Summary of spillover effect (continued)

\begin{tabular}{|c|c|c|c|c|}
\hline \multirow{2}{*}{ UK and Japan } & \multicolumn{2}{|c|}{ ABS } & \multicolumn{2}{|c|}{ PRO } \\
\hline & To UK & To Japan & & \\
\hline From UK & & $x$ & & \\
\hline From Japan & $\rightarrow$ & & & \\
\hline \multirow{2}{*}{ UK and China } & \multicolumn{2}{|c|}{ ABS } & \multicolumn{2}{|c|}{ PRO } \\
\hline & To UK & To China & To UK & To China \\
\hline From UK & & $\rightarrow$ & & $\rightarrow$ \\
\hline From China & $x$ & & $\rightarrow$ & \\
\hline \multirow{2}{*}{ UK and Korea } & \multicolumn{2}{|c|}{ ABS } & \multicolumn{2}{|c|}{ PRO } \\
\hline & To UK & To Korea & To UK & To Korea \\
\hline From UK & & $x$ & & $\rightarrow$ \\
\hline From Korea & $\rightarrow$ & & $\rightarrow$ & \\
\hline
\end{tabular}

Notes: Where ABS stands for daily average absolute bid ask spread. PRO stands for daily average proportional bid ask spread.

$\rightarrow$ indicates spillover effect exists; $\times$ shows no spillover effect.

\section{Robustness}

This section addresses some remaining concerns about the results obtained. In order to test for robustness we perform Granger Causality tests for all countries in the sample, using the same variables namely ABS and PRO.

The idea of Granger-causality is that a variable $X$ Granger-causes variable $Y$ if variable $Y$ can be better predicted using the histories of both $X$ and $Y$ than it can be predicted using the history of $Y$ alone. If, in a regression of $Y_{t}$ on lagged values of $Y_{t}$ and $X_{t}$, the coefficients of the $X_{t}$ values are zero then the series $X_{t}$ fails to Granger-cause $Y_{t}$. So consider the following regression model.

$$
Y_{t}=\sum_{j=1}^{m} \alpha_{j} Y_{t-1}+\sum_{i=1}^{n} \beta_{i} X_{t-1}+\varepsilon_{t}
$$

where $\varepsilon_{t}$ is the random error term, $\alpha_{j}$ is the coefficient on the lagged $Y$ values and $\beta_{i}$ is the coefficient on the lagged $X$ values. If $\beta_{i}$ is zero (for $i=1,2, \ldots, n$ ) then $X$ fails to Grangercause $Y$. In this case, variable $Y_{t}$ is liquidity (ABS and PRO) and $X_{t-1}$ is saved residuals from equation (2) for the selected countries. The number of lags to be included is chosen using the Akaike information Criterion.

Table 7 presents Granger causality results. Between the UK and the USA, there is a positive two way relationship captured by both ABS and PRO. This means that an increase in liquidity volatility in the UK (the USA) increases liquidity volatility in the US market (the UK) which is consistent with the results obtained from the GARCH-M model except for ABS from the USA to the UK. We also obtain a positive two way relationship between the UK and Hong Kong for both ABS and PRO. These two markets Granger cause each other. However, the GARCH-M model does not provide similar results. For instance, the GARCH-M model indicates that there is a spillover effect from the UK to Hong Kong captured only by ABS while PRO indicates a spillover effect from Hong 
Kong to the UK. Between the UK and Japan, UK liquidity volatility Granger causes Japan liquidity volatility while Japan liquidity volatility does not Granger cause the UK liquidity volatility which is opposite when compared with the result obtained from the GARCH-M model. Between the UK and China, there is a two way Granger causality relation captured by ABS only.

Table 7 Granger causality tests and GARCH-M for all countries

\begin{tabular}{|c|c|c|c|c|}
\hline & \multicolumn{2}{|c|}{$\begin{array}{c}\text { Granger Causality Test } \\
(\text { HO: } A \text { does not } \rightarrow B)\end{array}$} & \multicolumn{2}{|c|}{$\begin{array}{c}G A R C H-M \\
\left.\text { (The coefficient of } X_{t-1}\right)\end{array}$} \\
\hline & $A B S$ & $P R O$ & $A B S$ & $P R O$ \\
\hline $\mathrm{UK} \rightarrow \mathrm{USA}$ & $\begin{array}{c}5.5863 \\
(0.0039)^{* * *}\end{array}$ & $\begin{array}{c}2.3473 \\
(0.0962)^{*}\end{array}$ & $\begin{array}{c}0.00001 \\
(0.0000)^{*}\end{array}$ & $\begin{array}{l}-1.3 \mathrm{E}-06 \\
(0.0677)^{*}\end{array}$ \\
\hline $\mathrm{USA} \rightarrow \mathrm{UK}$ & $\begin{array}{c}4.6948 \\
(0.0094)^{* * *}\end{array}$ & $\begin{array}{c}7.6527 \\
(0.0005)^{* * *}\end{array}$ & $\begin{array}{c}0.1949 \\
(0.4838)\end{array}$ & $\begin{array}{l}9.67 \mathrm{E}-06 \\
(0.0867)^{*}\end{array}$ \\
\hline $\mathrm{UK} \rightarrow \mathrm{JAPAN}$ & $\begin{array}{c}4.1403 \\
(0.0162)^{* *}\end{array}$ & - & $\begin{array}{l}-0.00004 \\
(0.9487)\end{array}$ & - \\
\hline $\mathrm{JAPAN} \rightarrow \mathrm{UK}$ & $\begin{array}{c}0.0586 \\
(0.9430)\end{array}$ & - & $\begin{array}{c}0.0430 \\
(0.0932)^{*}\end{array}$ & - \\
\hline $\mathrm{UK} \rightarrow \mathrm{HK}$ & $\begin{array}{c}25.0161 \\
(0.0000)^{* * *}\end{array}$ & $\begin{array}{c}7.0884 \\
(0.0009)^{* * *}\end{array}$ & $\begin{array}{c}0.00013 \\
(0.0612)^{*}\end{array}$ & $\begin{array}{l}1.23 \mathrm{E}-07 \\
(0.2511)\end{array}$ \\
\hline $\mathrm{HK} \rightarrow \mathrm{UK}$ & $\begin{array}{c}5.2155 \\
(0.0056)^{* * *} \\
\end{array}$ & $\begin{array}{c}2.5628 \\
(0.0776)^{*}\end{array}$ & $\begin{array}{l}13.6107 \\
(0.7261)\end{array}$ & $\begin{array}{l}1.72 \mathrm{E}-05 \\
(0.0783)^{*}\end{array}$ \\
\hline $\mathrm{UK} \rightarrow \mathrm{CHINA}$ & $\begin{array}{c}42.0131 \\
(0.0000)^{* * *}\end{array}$ & $\begin{array}{c}0.8410 \\
(0.4316)\end{array}$ & $\begin{array}{c}2.3 \mathrm{E}-07 \\
(0.0000)^{* * *}\end{array}$ & $\begin{array}{c}0.0201 \\
(0.0000)^{* * * *}\end{array}$ \\
\hline $\mathrm{CHINA} \rightarrow \mathrm{UK}$ & $\begin{array}{c}41.6116 \\
(0.0000)^{* * *}\end{array}$ & $\begin{array}{c}2.9476 \\
(0.0530)^{*}\end{array}$ & $\begin{array}{l}2.5249 \\
(0.6509)\end{array}$ & $\begin{array}{c}6.4 \mathrm{E}-09 \\
(0.0005)^{* * *}\end{array}$ \\
\hline $\mathrm{UK} \rightarrow \mathrm{KOREA}$ & $\begin{array}{c}0.8071 \\
(0.4465)\end{array}$ & $\begin{array}{c}14.573 \\
(0.0000)^{* * *}\end{array}$ & $\begin{array}{c}0.0001 \\
(0.7406)\end{array}$ & $\begin{array}{c}1.72 \mathrm{E}-11 \\
(0.0242)^{* *}\end{array}$ \\
\hline $\mathrm{KOREA} \rightarrow \mathrm{UK}$ & $\begin{array}{c}0.4192 \\
(0.6577)\end{array}$ & $\begin{array}{c}3.4682 \\
(0.0316)^{*}\end{array}$ & $\begin{array}{c}-0.5954 \\
(0.0183)^{* *}\end{array}$ & $\begin{array}{c}0.0233 \\
(0.0009)^{* * *}\end{array}$ \\
\hline
\end{tabular}

Notes: The table shows Granger causality tests and the GARCH-M model (tests of spillovers) between UK and other countries which includes the USA, Japan, Hong Kong (HK), China and Korea. We test the null hypothesis that liquidity shock in country A does not Granger cause the liquidity shock in country B. We report the $\chi^{2}$ and $p$-value (in parenthesis) for each test. From the GARCH$\mathrm{M}$ model, we report the coefficient of $X_{t-1}$ and $p$-value (in parenthesis) for each test. $*, * *, * * *$ indicate statistically significant at $10 \%, 5 \%$ and $1 \%$, respectively.

When we use PRO, liquidity volatility in China Granger causes liquidity volatility in the UK while liquidity volatility in the UK does not Granger cause liquidity volatility in China. Again when we compare findings between Granger-causality test and the GARCH-M, there is a consistent spillover effect from the UK to China (ABS) and from China to the UK (PRO). Finally, the study shows a two way relationship between the UK and Korea for PRO while it does not show any Granger causality between the UK and Korea for ABS. Generally speaking, this section confirms spillover effects for all countries obtained from GARCH-M model except for the UK and Japan group. 


\subsection{The effect of foreign exchange rate}

Up to this point, this study examined liquidity volatility spillover using a single currency. The local currency is converted into British pound. In order to address the effect of foreign exchange rate if any on liquidity-volatility spillover effect, we repeat all tests with local currency for all six countries (not presented). The study finds that previously presented results remain qualitatively the same.

\section{Conclusion}

This empirical study investigates liquidity volatility spillovers between the UK and East Asian stock markets (Japan, China, Hong Kong and Korea) and between the UK and the USA from 2006 to 2010 adopting GARCH-M models following Hamao et al. (1990) and Granger causality tests. This study presents evidence that liquidity volatility for all countries is high and persistent. We also confirm the existence of liquidity volatility spillover effects. As we use different measures of liquidity, results are mixed for each country, for instance, we find a spillover effect from the UK to Hong Kong with ABS but there is no spillover effect when we use PRO. However, Granger causality tests clearly show that there is spillover effect between the UK and Hong Kong. Also spillover effects between the UK and China are found in both directions. The study also finds spillover effects between the UK and Korea. Finally, the existence of liquidity spillover effects between the UK and Japan are ambiguous.

The evidence suggests that the risk associated with market making between countries, which are in different continents, is strongly correlated. As conventional market contagion theory suggests, risk is spreading due to the increased interdependency of the global stock market. This study supports the above theory by providing evidence which shows significant spillover effects between the UK and selected Asian countries. These results have implications for international stock market portfolio choice. If the markets such as the USA, the UK and other Asian countries have become highly integrated, the systematic risk in one market is now predominantly common risk across the markets. Therefore, diversification of risk requires investors to look beyond these markets because there is now less opportunity for diversifying risk at least across our selected markets.

This empirical study has some limitations though which stem from unavailability of data and non-synchronised trading hours. Hamao et al. (1990) use open to close and close to open stock price data set in order to avoid issues arising from non-synchronised trading hours. However, daily opening bid and ask price is not available, so the study uses close to close price data set. Finally, the financial crisis period (2007-2009) is included in the sample, but the study could not test liquidity spillover effects before and after the crisis period separately due to non-stationary variables.

\section{References}

Angelidis, T. and Andrikopoulos, A. (2010) 'Idiosyncratic risk, returns and liquidity in the London stock exchange: a spillover approach', International Review of Financial Analysis, Vol. 19, No. 3, pp.214-221.

Bayoumi, T. and Swiston, A.J. (2009) 'Foreign entanglements: estimating the source and size of spillovers across industrial countries', IMF Staff Papers, Vol. 56, No. 2, pp.353-383. 
Bernardo, A.E. and Welch, I. (2003) Liquidity and Financial Market Runs, Yale ICF Working Paper No. 02-11.

Blattberg, R.C. and Gonedes, N.J. (1974) 'A comparison of the stable and student distributions as statistical models for stock prices', The Journal of Business, Vol. 47, No. 2, pp.244-280.

Bollerslev, T. (1986) 'Generalized autoregressive conditional heteroscedasticity', Journal of Econometrics, Vol. 3, No. 1, pp.307-328.

Caporale, G.M., Pittis. N. and Spagnolo, N. (2006) 'Volatility transmission and financial crises', Journal of Economics and Finance, Vol. 30, No. 3, pp.376-390.

Chan, J., Jain, R. and Xia, Y. (2005) Market Segmentation, Liquidity Spillover, and Closed-end Country Fund Discounts, Working Paper, Temple University, Philadelphia, PA, USA.

Chanchaoenchai, K. and Dibooglu, S. (2006) 'Volatility, spillovers and contagion during the Asian crisis: evidence from six Southeast Asian stock markets', Emerging Markets Finance and Trade, Vol. 42, No. 2, pp.4-17.

Chen, S. and Poon, S.H. (2007) International Stock Market Liquidity and Financial Crisis, Working Paper, University of Manchester, Manchester, UK.

Chordia, T., Roll, R. and Subrahmanyam, A. (2000) 'Commonality in liquidity', Journal of Financial Economics, Vol. 56, No. 1, pp.3-28.

Chordia, T., Sarkar, A. and Subrahmanyam, A. (2005) 'An empirical analysis of stock and bond market liquidity', The Review of Financial Studies, Vol. 18, No. 1, pp.85-129.

Chordia, T., Sarkar, A. and Subrahmanyam, A. (2006) Liquidity Spillover and CrossAutocorrelations, Working Paper, Emory University, Atlanta, Georgia.

Clark, P.K. (1973) 'The subordinated stochastic process model with finite variance for speculative prices', Econometrica, Vol. 41, No. 1, pp.135-155.

De Santis, G. and Imrohoroglu, S. (1997) 'Stock returns and volatility in emerging financial markets', Journal of International Money and Finance, Vol. 16, No. 4, pp.561-579.

Deuskar, P. (2006) Extrapolative Expectations: Implications for Volatility and Liquidity, Working Paper, University of Illinois, Urbana-Champaign, IL, USA.

Engle, R.F. (1982) 'Autoregressive conditional heteroscedasticity with estimates of the variance of United Kingdom inflation', Econometrica, Vol. 50, No. 4, pp.987-1007.

Engle, R.F., Ito, T. and Lin, W. (1990) 'Meteor showers or heat waves? Heteroskedastic intra-daily volatility in the foreign exchange market', Econometrica, Vol. 58, No. 3, pp.525-542.

Eun, C.S. and Shim, S. (1989) 'International transmission of stock market movements', Journal of Financial and Quantitative Analysis, Vol. 24, No. 2, pp.241-255.

Frank, N., Hermosillo, B.G. and Hesse, H. (2008) Transmission of Liquidity Shocks: Evidence from the 2007 Subprime Crisis, IMF Working Paper, WP/08/200.

French, K. and Roll, R. (1986) 'Stock return variances: the arrival of information and the reaction of traders', Journal of Financial Economics, Vol. 17, No. 1, pp.5-26.

French, K.R., Schwert, G.W. and Stambaugh, R.E. (1987) 'Expected stock returns and volatility', Journal of Financial Economics, Vol. 19, pp.3-29.

Galariotis, E. and Giouvris, E. (2007) 'Liquidity commonality in the London stock exchange', Journal of Business Finance \& Accounting, Vol. 34, No. 1, pp.374-388.

Galariotis, E. and Giouvris, E. (2009) 'Systematic liquidity and excess returns: evidence from the London stock exchange', Review of Accounting and Finance, Vol. 8, No. 3, pp.279-307.

Hamao, Y., Masulis, R.W. and Ng, V. (1990) 'Correlations in price changes and volatility across international stock markets', Review of Financial Studies, Vol. 3, No. 2, pp.81-307.

Hameed, A., Kang, W. and Viswanathan, S. (2006) Stock market declines and liquidity, Working Paper, National University of Singapore.

Hasbrouck, J. and Seppi, D.J. (2001) 'Common factors in prices, order flows and liquidity', Journal of Financial Economics, Vol. 59, pp.383-411. 
Huberman, G. and Halka, D. (2001) 'Systematic liquidity', Journal of Financial Research, Vol. 24, No. 2, pp.161-178.

In, F., Kim, S.B., Yoon, J.H. and Viney, C. (2001) 'Dynamic interdependence and volatility transmission of Asian stock markets evidence from the Asian crisis', International Review of Financial Analysis, Vol. 10, No. 1, pp.87-96.

Jang, H.Y. and Sul, W.S. (2002) 'The Asian financial crisis and the co-movement of Asian stock markets', Journal of Asian Economics, Vol. 13, No. 1, pp.94-104.

Jeremie, C.S. and Jean, P.F. (2008) Asia-Europe: The Third Link, European Commission, Directorate-General for Economic and Financial Affairs, Economic Papers, No. 352, pp.1-35.

Karolyi, G.A. (1995) 'A multivariate GARCH model of international transmissions of stock returns and volatility: the case of the United States and Canada, Journal of Business \& Economic Statistics, Vol. 13, No. 1, pp.11-25.

Kim, S., Moshirian, F. and Wu, E. (2005) 'Dynamic stock market integration driven by the European monetary union: an empirical analysis', Journal of Banking and Finance, Vol. 29, No. 10, pp.2475-2502.

Koutmos, G. and Booth, G.G. (1995) 'Asymmetries in the conditional mean and the conditional variance: evidence from nine stock markets', Journal of Economics and Business, Vol. 50, No. 3, pp.277-290.

Leong, S.C. and Flemingham, B. (2003) 'The interdependence of share markets in the developed economies of East Asia', Pacific-Basin Finance Journal, Vol. 11, No. 2, pp.219-237.

Longin, F. and Solnik, B. (1995) 'Is the international correlation of equity returns constant: 19601990?' Journal of International Money and Finance, February, pp.3-26.

Martens, M. and Poon, S. (2001) 'Returns synchronization and daily correlation dynamics between international stock markets', Journal of Banking and Finance, Vol. 25, No. 10, pp.1805-1827.

Meric, I., Kim. S., Kim, J.H. and Meric, G. (2008) 'Co-Movements of U.S., U.K., and Asian stock markets before and after September 11, 2001', Journal of Money, Investment and Banking, Vol. 3, pp.48-57.

Nelson, D.B. (1991) 'Conditional heteroscedasticity in asset returns', Econometrica, Vol. 59, No. 2, pp.343-370.

Ng, A. (2000) 'Volatility spillover effects from Japan and the US to the Pacific-Basin', Journal of International Money and Finance, Vol. 19, pp.207-233.

Nicolo, G.D. and Ivaschenko, I. (2008) Financial Integration and Risk-Adjusted Growth Opportunities, IMF Working Paper, WP/08/126.

Schwert, G.W. (1990) 'Stock volatility and the crash of '87', The Review of Financial Studies, Vol. 3, No. 1, pp.77-102.

Subrahmanyam, A. (2007) 'Liquidity, return and order-flow linkages between REITs and the stock market', Real Estate Economics, Vol. 35, No. 3, pp.383-408.

Tang, D.Y. and Yan, H. (2006) Liquidity, Liquidity Spillover, and Credit Default Swap Spreads, Working Paper, Kennesaw State University and University of Texas, Austin, TX, USA.

Theodossiou, P. and Lee, U. (1993) 'Mean and volatility spillovers across major national stock markets: further empirical evidence', Journal of Financial Research, Vol. 16, No. 4, pp.337-350.

Theodossiou, P., Kahya, E., Koutmos, G. and Christofi, A. (1997) 'Volatility reversion and correlation structure of returns in major international stock markets', Financial Review, Vol. 32, No. 2, pp.205-224. 


\section{Notes}

1 Please see Kim et al. (2005). They provide a financial explanation about correlations between stock markets and find significant stronger correlation after the introduction of the euro in 1999. This indicates stronger integration for EMU countries and thus higher probability of spillover effects.

2 Chordia et al. (2000), Huberman and Halka (2001) and Hasbrouck and Seppi (2001) look into common factors in the US market. Galariotis and Giouvris $(2007,2008)$ look into the UK market.

3 Tang and Yan (2006) find significant liquidity spillovers from bond, stock and option markets to the CDS market. Subrahmanyam (2007) extends the study to cover liquidity, returns and order flow between the equity market and the real estate investment trusts.

4 See Longin and Solnik (1995). They argue that increased capital market integration goes hand-in-hand with increased cross-county correlation.

5 Hameed et al. (2006) show that market declines affect both liquidity and liquidity commonality. After large and negative market returns, commonality in liquidity increases and peaks with liquidity crisis and illiquidity in one industry spillovers to the other industry.

6 Eun and Shim (1989) analyse international stock market interdependence by using VAR and documented the existence of substantial interdependence among national stock markets.

$7 \quad$ Also see: French et al. (1987), Nelson (1991), Lin et al. (1994), Karolyi (1995), Koutmos and Booth (1995), De Santis and Imrohoroglu (1997), Ng (2000), In et al. (2001), Worthington and Higgs (2004). These studies investigate relationships between stock returns and volatility.

8 Please see the report of 17th APEC Ministerial Meeting, Busan, Korea, 15-16 November 2005 (http://www.mofa.go.jp/policy/economy/apec/2005/bogor.pdf).

9 Volatility associated with bad news in New York is transmitted to Tokyo and London the next trading day and from Tokyo to London. This suggests that the transmission of volatility is asymmetric and negative innovations in foreign markets increase volatility the next day more than positive innovations in foreign markets.

10 Even a small change in liquidity could cause a financial market run in which prices can fall due to investors' fear.

11 Our US data starts from 10 April 2006.

12 Non-stationary time series is caused by random walk with or without a drift and deterministic trends in the series. In other words, it does not have a constant long-term mean and a constant variance independent of time. Thus, non-stationary data is unpredictable and cannot be modelled or forecasted because it has a variable variance and a mean that does not remain near or returns to a long-run mean over time. Also, holiday schedules in China, Hong Kong and Korea are varying in each year due to the lunar calendar system. This could cause nonstationary time series.

13 The test results are available upon request.

14 The study estimates equation (5) at time $t-1$ for country A and save residuals denoted by $X_{t-1}$. Then we add the saved residuals $\left(X_{t-1}\right)$ into the variance equation of equation 6 for country B which captures spillover effect from country A to country B.

15 This outcome is more or less expected given that in a crisis the mean value of illiquidity will start increasing. For a time series to be stationary, it is necessary that the mean remains stable over time.

16 Data source: http://www.cia.gov/library/publications/the-world-factbook/index.html 